\title{
COVID-19 AND INTELLECTUAL PROPERTY LAW: COMPULSORY LICENSING AND THE ACCESS TO COVID-19 TREATMENT *
}

\section{Anaísa Correia de Oliveira**}

\begin{abstract}
Summary: 1. Introduction; 2. Compulsory Licenses; 3. Alternatives to Compulsory Licensing; 3.1. Patent Pools; 3.2. Voluntary Licenses; 3.3. Waiving TRIPS Intellectual Property Rights provisions; 4. Conclusion.
\end{abstract}

SuMÁrIO: 1. Introdução; 2. Licenças Compulsórias; 3. Meios Alternativos; 3.1. Patent Pools; 3.2. Licenças Voluntárias; 3.3. Pedido de suspensão do Regime de Propriedade Intelectual do Acordo TRIPS; 4 . Conclusão.

\begin{abstract}
This essay concerns the problematic of the access to Covid-19 treatment at an international scale and the role of Intellectual Property Law. As in past public health outbreaks, one of the most raised questions is the possibility of patent holder's rights being an obstacle to accessing treatment. Since the beginning of the pandemic, Compulsory Licensing has been presented as the Intellectual Property Law mechanism capable of guaranteeing Covid-19 treatment globally and effectively. We propose to analyse this figure and its possible alternatives: Voluntary Licensing, Patent Pools and the Proposal to waive TRIPS Intellectual Property provision. We will then assess which is the most effective solution to overcome this humanitarian crisis without compromising the balance between the right to health and intellectual property rights.
\end{abstract}

KeYwords: Intellectual Property Law; Covid-19; Compulsory Licenses; Patent Pools; Voluntary Licenses; Proposal to waive TRIPS Intellectual Property provisions.

RESUMO: O presente artigo incide sobre a problemática existente entre o acesso ao tratamento da COVID-19 e o Direito de Propriedade Intelectual a nível internacional. Tal como em epidemias anteriores, uma das questões mais debatidas é a

* This paper was written for the final evaluation of Intellectual Property Law course in December 2020 .

** Master's Student in Law and Technology at NOVA School of Law. 


\section{ANAÍSA CORREIA DE OLIVEIRA}

possibilidade dos direitos dos inventores constituírem um obstáculo ao acesso ao tratamento. Desde o início desta pandemia, as Licenças Compulsórias foram apresentadas como o mecanismo capaz de garantir esse acesso de forma rápida e universal. Neste artigo propomo-nos a analisar esta figura legal e possíveis meios alternativos: Licenças Voluntárias, Patent Pools e até o Pedido de suspensão do Regime de Propriedade Intelectual do Acordo TRIPS. Após uma comparação, tentaremos desvendar qual a solução mais eficaz para se alcançar o fim desta crise humanitária sem colocar em causa o equilíbrio entre o direito à saúde e os direitos de propriedade intelectual.

Palavras-chave: Direito da Propriedade Intelectual; Covid-19; Licenças Compulsórias; Patent Pools; Licenças Voluntárias; Pedido de suspensão do Regime de Propriedade Intelectual do Acordo TRIPS. 


\section{INTRODUCTION}

Covid-19 pandemic knows no limits or borders: it is long-term locking down entire cities and devastating the world's greatest economies. Researchers and inventors rushed to create treatments, medicines and devices capable of beating this global threat. In an extraordinary short period of time, vaccines were developed and are now being commercialized.

Since its beginning, questions have been raised about the possibility of intellectual property law being an obstacle to stop this pandemic.

Discussion regarding the patent holder's rights versus access to medicines is a topic now revisited: to encourage future innovation, society grants to inventors exclusive rights in exchange for sharing their inventions. However, in these private monopolies, once the patents are granted, pharmaceutical companies control medicines prices and licenses. Those rights conferred to patentees affects the production and, therefore, the accessibility to such treatments.

This would normally impact low-income countries that are not capable of purchasing or producing these products, as in prior public health crises. ${ }^{1} \mathrm{How}$ ever, due to the escalating devastation and spreading of this coronavirus, its treatment is an essential good exponentially demanded, meaning all world nations may have difficulties to obtain it. Therefore, if patentees cannot produce enough medicines for 7,8 billion people, or do not allow others to produce them, how can governments guarantee its citizens' fundamental right to health?

Compulsory licensing has been indicated as the solution for balancing the patentee rights and the public interest. This mechanism is believed to be the most effective in ensuring universal and cheap access to COVID-19 drugs and vaccines and its use has been encouraged. ${ }^{23}$

1 Katarina Foss-Solbrekk. "Safeguarding public health in the wake of hegemonic intellectual property rights - Two means to this end?", Stockholm Intellectual Property Law Review 2, no. 1 (June 2019): 80, http://www.stockholmiplawreview.com/wp-content/uploads/2019/05/Online_IP_nr1_2019_A4_Safeguarding-public-health.pdf

2 In the 73rd World Health Assembly, the World Health Organization (WHO) recommended governments to make use of TRIPS Agreement flexibilities (moreover, Compulsory Licensing), World Health Organization, "Covid-19 response”, WHA73.1, May 19, 2020, https://apps.who. int/gb/ebwha/pdf_files/WHA73/A73_R1-en.pdf.

3 In March 2020, Israel had already issued a compulsory patent license. Thiru, "Israel issues com- 
Nonetheless, many have raised concerns about granting compulsory licenses. Voluntary licensing, patent pools and even a Proposal for waiving TRIPS Intellectual Property Law provisions were presented as alternatives.

\section{Compulsory LiCenses}

What is this legal mechanism of compulsory licensing? Compulsory Licenses were established in the Paris Convention of $1883^{4}$ and regulated in detail in the TRIPS Agreement as an exemption to the rights conferred to the patent holder. ${ }^{5}$

Under a Compulsory License, the patentee must tolerate the exploitation of his invention by a third person or by the government itself when there is a public interest in broader access to the invention considered to be more important than the private interest of the patent holder exclusive rights. ${ }^{6}$ This public interest must be essential - an example, public health. ${ }^{7}$

Compulsory Licensing is an exceptional situation that must fulfil requirements. Article 31 TRIPS enumerates these preliminary conditions, stating

pulsory license to allow the government to import generic versions of Kaletra", Blog, Knowledge Ecology International, 2020, https://www.keionline.org/32503; Minister of Health of Israel, A Permit to the State to Exploit an Invention, 2020, https://www.keionline.org/wp-content/uploads/APermit-to-the-State-to-Exploit-an-Invention-Pursuant-to-Chapter-Six-Article-Three-of-the-PatentsLaw-5727-1967.pdf. Nevertheless, the patentee (AbbVie) announced that they would not enforce the patent (Phil Taylor, "AbbVie won't enforce patents for COVID-19 drug candidate Kaletra," Blog, Pharmaphorum, 2020, https://pharmaphorum.com/news/abbvie-wont-enforce-patents-for-covid19-drug-candidate-kaletra/).

4 "Paris Convention for the Protection of Industrial Property," (as amended on September 28, 1979), Article 5, https://wipolex.wipo.int/en/text/287556 .

5 "Agreement on Trade-Related Aspects of Intellectual Property Rights," (original version), Article 31, https://www.wto.org/english/docs_e/legal_e/31bis_trips_01_e.htm

6 As stated by Jerome Reichman and Catherine Hasenzahl, Non-voluntary Licensing of Patented Inventions: Historical Perspectives, Legal Frameworks under Trips and an Overview of the Practice in Canada and in United States of America, 5 (Geneva: UNCTAD/ICTSD, 2002), 1, (PDF) Non-voluntary Licensing of Patented Inventions Historical Perspective, Legal Framework under TRIPS, and an Overview of the Practice in Canada and the USA (researchgate.net): Compulsory Licensing is "the practice by a government to authorise itself or third parties to use the subject matter of a patent without the authorisation of the right holder for reasons of public policy".

7 Vítor Palmela Fidalgo, As Licenças Compulsórias de Direitos de Propriedade Intelectual (Lisbon: Almedina, 2016). 
that to grant a license, a State must: provide adequate remuneration to the respective right holder; if not in the event of "a national emergency or other circumstance of extreme urgency", it must attempt to negotiate a voluntary license with the right holder prior to issuing a compulsory one; use the patent solely for the purpose of its authorisation; authorise the Compulsory Licensing "predominantly for the supply of the domestic market"; construct the Compulsory Licensing to be non-exclusive and subject it to judicial review. Nevertheless, these conditions are not obligatory if the license aims to remedy anti-competitive practices, as Article 31(k) TRIPS affirms.

Covid-19 pandemic is a situation of national emergency or extreme urgency $^{8}{ }^{8}$, meaning countries will act lawfully, under Article 31(b) TRIPS, if they choose to use it. Until the Doha Declaration of $2001^{10}$ and the 2003 TRIPS Council Decision ${ }^{11}$, this figure only apparently protected public interests, especially public health. Countries with little or no manufacturing capabilities (mostly, least developed countries), were unsure of how to use TRIPS flexibilities, as Compulsory Licenses. ${ }^{12}$ This issue was clearly visible in the previous HIV/AIDS outbreak in the late 1990s. ${ }^{13}$

\footnotetext{
8 As stated in World Trade Organization, "Declaration on the Trips Agreement and Public Health", WT/MIN(01)/DEC/2, November 9-14, 2001, https://www.wto.org/english/thewto_e/minist_e/ min01_e/mindecl_trips_e.pdf, Clause 5(c): "Each Member has the right to determine what constitutes a national emergency or other circumstances of extreme urgency, it being understood that public health crises, including those relating to HIV/AIDS, tuberculosis, malaria and other epidemics, can represent a national emergency or other circumstances of extreme urgency." (bold by us).
}

9 Hilary Wong, "The case for compulsory licensing during COVID-19," Journal of Global Health 10, No. 1, (June 2020), http://www.jogh.org/documents/issue202001/jogh-10-010358.pdf .

10 World Trade Organization, "Declaration on the Trips Agreement and Public Health".

11 General Council of the World Trade Organization, "Decision of the General Council of 30 August 2003", WT/L/540 and Corr.1, September 1, 2003, https://www.wto.org/english/tratop_e/ trips_e/implem_para6_e.htm.

12 "Despite the existence of CLs, countries with little or no local manufacturing capabilities were unable to produce drugs locally and at the same time prohibited from importing medicines under a license pursuant to Article $31(\mathrm{f})$. For countries able to produce drugs, the prices offered under a CL were still not affordable. This issue escalated in the wake of the HIV/AIDS epidemic in the late 1990s. During this time, the right to health appeared precarious as IPRs prevailed over individuals' inability to access affordable drugs." Foss-Solbrekk, "Safeguarding public health": 80.

13 Highlighting this, Mary K. Schug, "Promoting Access to HIV/AIDS Pharmaceuticals in SubSaharan Africa within the Framework of International Intellectual Property Law," Minnesota Journal of Law \& Inequality 19 (2001), Promoting Access to HIV/AIDS Pharmaceuticals in Sub-Saharan Africa within the Framework of International Intellectual Property Law (umn.edu). 
In order to be useful, the legal regime needed interpretation and so, in 2001, the Doha Declaration refined it, clarifying that TRIPS must be interpreted in light of the obligations surrounding the right to health and reaffirmed Members' right to utilise TRIPS flexibilities to circumvent intellectual property rights (IPRs) for improving access to medicines. Moreover, TRIPS Council reached a decision of adopting Paragraph 6 of the Doha Declaration in $2003^{14}$, which establishes that least developed countries and other countries lacking manufacturing capacities can import drugs under a Compulsory License. ${ }^{15}$ This Decision was incorporated into TRIPS as the new 'Article 31 bis' in January of $2017^{16}$, providing exceptions, especially to article $31(\mathrm{f})$. Article $31(\mathrm{f})$ is a provision which requires that any Compulsory License granted by World Trade Organization (WTO) Members must be "predominantly for the supply of the domestic market of the Member authorizing such use". Now, 31 bis permits WTO Members' to grant a "special" Compulsory License for export without that limitation.

However, difficulties remained: WTO Members continue to dissuade the use of Compulsory Licenses, since the Declaration failed to mediate the tensions between them and the procedural and political difficulties of employing compulsory licensing inhabit now not only in Article 31 but also in 31 bis. This new article presents, among others, preliminary notification requirements, obliging importing and exporting countries to notify the TRIPS Council of their intent to issue/grant a Compulsory License, to specify the characteristics of the products - name, quantities, etc - and of the importation/exportation, information that shall be published and available online.

Notwithstanding, the grounds for issuing Compulsory Licenses remain at the discretion of States themselves ${ }^{17}$, that must enact legislation to imple-

14 General Council of the World Trade Organization, "Decision of the General Council of 30 August 2003".

15 World Trade Organization, "Declaration on the Trips Agreement and Public Health," paragraph 6: "We recognize that WTO Members with insufficient or no manufacturing capacities in the pharmaceutical sector could face difficulties in making effective use of compulsory licensing under the TRIPS Agreement. We instruct the Council for TRIPS to find an expeditious solution to this problem and to report to the General Council before the end of 2002."

16 "Agreement on Trade-Related Aspects of Intellectual Property Rights" (as amended on January 23, 2017), https://www.wto.org/english/docs_e/legal_e/31bis_trips_01_e.htm.

17 Paragraph 5(b) of the Doha Declaration manifests that each member retains "the freedom to determine the grounds upon which such licenses are granted," provided that Article 31 requirements are adhered to. 
ment their provisions. As a consequence, compulsory regimes differ from State to State, since governments can determine autonomously the scope of the procedural conditions and the grounds for issuance. ${ }^{18}$ These grounds also vary due to bilateral and multilateral free-trade agreements (FTAs) signed between States, which usually restrict those grounds and lead to the adoption of stronger Intellectual Property standards.

This is a main disadvantage of this TRIPS flexibility. Properly regulating Compulsory Licenses at the national level is essential for its usefulness and effectiveness.

Moreover, high income countries face another considerable problem. Although Article 31bis TRIPS is not perfect, it is considered the only solution for the export restriction of 31(f). Nevertheless, Australia, Canada, European Union, Iceland, Japan, New Zealand, Norway, Switzerland and the United States unilaterally committed not to subscribe this system as importers ${ }^{19}$, even in situations of national emergency/extreme urgency. This impacts not only the affordability and access to generic medicines in these countries, but since the economies of scale that could have been harnessed by exporting to them are curtailed, the price of the generic medicines that could be produced for other WTO Members may be higher. ${ }^{20}$

Many have appealed to these countries to reconsider this decision. ${ }^{21} \mathrm{How}-$ ever, can high income countries opt-back into Article 31 bis system? It has been stated that members have the option "to modify their status as users

18 Studies reveal how the basis for granting a Compulsory License varies depending on national laws. Carolyn Deere, "The Implementation Game: The TRIPS Agreement and the Global Politics of Intellectual Property Reform," (Oxford University Press, 2009): 92-93, https://papers.ssrn.com/sol3/ papers.cfm?abstract_id=1405224; and WIPO, "Survey on Compulsory Licenses Granted by WIPO Members to Address Anti-Competitive Uses of Intellectual Property," CDIP/4/4/REV.Study/INF/5, October 4, 2011, Table 2, https://www.wipo.int/meetings/en/doc_details.jsp?doc_id=187423.

19 General Council, "Decision," Article 1(b), footnote 3.

20 Presenting a complete explanation of this situation, Christopher Garrison, "Never say never Why the High Income Countries that opted-out from the Art. 31bis WTO TRIPS system must urgently reconsider their decision in the face of the Covid-19 pandemic," Blog, Medicines Law \& Policy, April 8, 2020, https://medicineslawandpolicy.org/2020/04/never-say-never-why-the-high-income-countries-that-opted-out-from-the-art-31bis-wto-trips-system-must-urgently-reconsider-their-decision-inthe-face-of-the-covid-19-pandemic/.

21 James Love, "Open letter asking 37 WTO Members to declare themselves eligible to import medicines manufactured under compulsory license in another country, under 31 bis of TRIPS Agreement", Blog, Knowledge Ecology International, April 7, 2020, https://www.keionline.org/32707. 
of the system at any time" and the Decision of Implementing Paragraph 6 "does not seem to prohibit members that opted out from opting back in"22, although some disagree. ${ }^{23}$ Nevertheless, the global emergency seems enough justification.

In the case of European Union, challenges double. First of all, there is no compulsory licensing general regime in the EU. The EU Regulation on Compulsory Licensing relating to Pharmaceuticals states that Compulsory Licenses can only be granted by individual EU Member States by their competent authorities under national patent law and only for their specific territories..$^{24}$ Moreover, opting out of the Decision meant that the EU cannot import pharmaceutical products produced under a Compulsory License in third countries but also in other EU Member States. ${ }^{25}$ This means that, if the EU does not revisit its decision to opt-out, its Member States "have to rely on their own domestic production of pharmaceuticals and vaccines". 2627

If the access to COVID-19 treatments can be so problematic in high income countries, difficulties are even greater in low-income nations. Nevertheless, past outbreaks conclusions show that Compulsory Licensing has always been pointed out as a relevant tool to be used by both developed and least

22 WeinianHu,CompulsoryLicensingandAccesstoFuture Covid-19Vaccines, 2(Brussels:CEPS, 2020), https://www.ceps.eu/ceps-publications/compulsory-licensing-and-access-to-future-covid19-vaccines/.

23 Frederick M. Abbott, "The WTO Medicines Decision: World Pharmaceutical Trade and the Protection of Public Health", The American Journal of International Law 99, (2005): 336, https:// www.who.int/intellectualproperty/submissions/Abbott\%20proofs.pdf.

24 Regulation (EC) No 816/2006 of 17 May 2006 on compulsory licensing of patents relating to the manufacture of pharmaceutical products for export to countries with public health problems, Article 3, https://eur-lex.europa.eu/legal-content/EN/TXT/PDF/?uri=CELEX:32006R0816\&f rom $=\mathrm{EN}$

25 EU Regulation on Compulsory Licensing relating to Pharmaceuticals, Article 13.

26 Caranina Colpaert, "Compulsory Licensing for Pharmaceuticals in the EU: A Reality Check", Blog, Bill of Health, October 21, 2020, https://blog.petrieflom.law.harvard.edu/2020/10/21/compulsory-licensing-eu-pharma/ .

27 Data exclusivity and subjective scope are possible blocks to the effective use of Compulsory License as well. Nonetheless, the exclusivity of data can be dismissed by a waiver provided in Article 18 and questions regarding who can take the initiative of granting the Compulsory License can be answered by Article 6, both of the EU Regulation on Compulsory Licensing relating to Pharmaceuticals. 
developed countries because they increase drug supply and decrease prices. ${ }^{28}$ However, countries usually shy away from it, not only because of FTAs, but also because they fear trade retaliation and Compulsory Licenses' complicated nature that may lead to complex and lengthy judicial procedures. ${ }^{29}$

For all the disadvantages presented, and because of the urgent nature of this pandemic, many have argued that Compulsory Licensing is not an effective way to provide COVID-19 treatment globally. Due to its rules applying only on a case-by-case and product-by-product basis, it is believed its use will slow down the ability of countries to scale up production of needed COVID-19 medical products. ${ }^{30}$

\section{Alternatives to Compulsory licensing}

There are different alternatives to Compulsory Licensing, now spotlighting Patent Pools and Voluntary Licenses.

\section{1. Patent pools}

C-TAP and Open Covid Pledge are two examples of currently active Patent Pools. ${ }^{31}$

28 As stated in Médecins Sans Frontières, A Fair Shot for Vaccine Affordability: Understanding and addressing the effects of patents on access to newer vaccines (Geneva: Médecins Sans Frontières, September 2017): 18, https://msfaccess.org/fair-shot-vaccine-affordability: "The use of compulsory licences has proven to be an effective way of overcoming patent barriers to access critical health products and could also be employed as a threat by governments in their price negotiations."

29 This was noted especially in the HIV/AIDS epidemic. Hilary Wong, "The case for compulsory licensing," 2.

30 As stated by Ronald Labonte and Mira Johri, "COVID-19 drug and vaccine patents are putting profit before people", Blog, The Conversation, November 5, 2020, https://theconversation.com/ covid-19-drug-and-vaccine-patents-are-putting-profit-before-people-149270.

31 "WHO Covid-19 Technology Access Pool", World Health Organization, https://www.who.int/ emergencies/diseases/novel-coronavirus-2019/global-research-on-novel-coronavirus-2019-ncov/ covid-19-technology-access-pool and Open Covid Pledge, https://opencovidpledge.org/. 
Patent Pools compile data on clinical trials, technologies, and other essential information for the development of a treatment. They allow companies and governments to legally rely on the knowledge provided by other companies about patented inventions placed in the Pool under an open license.

Many believe they encourage and motivate innovators and simultaneously secure equal and affordable access to medicines. ${ }^{32}$ Patent Pools do not force pharmaceutical companies into Compulsory Licensing but instead negotiate with patentees for public-health driven licenses. They are indicated as being more effective in terms of time as well.

Patent Pools lower transaction costs, reduce both litigation and the expense of negotiation with a myriad of patent holders, but most importantly, facilitate innovation.

Its disadvantages mainly concern their creation (long time for formation and difficulties to find patent administrators), the possibilities of leading to competition law violations and the requirement for an independent expert to evaluate the member's patents. Moreover, Patent Pools are only useful if companies voluntarily participate and contribute to the pool.

\section{2. VOLUNTARY LICENSES}

Patent Pools and Compulsory Licensing both promote another alternative, preferred by patentees: voluntary licenses.

This alternative is a "private contractual agreement between right holders and second parties, which stipulate the terms and conditions for the entry of particular medicines in a designated market". ${ }^{33}$ They are not subject to Article 31 TRIPS. The parties - generic firms, States or Patent Pools and

32 For example, the UN-funded Medicines Patent Pool was a very special tool to improve the access to HIV/AIDS, tuberculosis and malaria treatments. Medicines Patent Pool, Annual Report 2016: Expanding for Better Treatment Options, (Geneva: Medicines Patent Pool, 2016), https://annual-report-2016.medicinespatentpool.org/ .

33 Peter Beyer, "Developing Socially Responsible Intellectual Property Licensing Policies: Nonexclusive Licensing Initiatives in the Pharmaceutical Sector," in Research Handbook on Intellectual Property Licensing, ed. Jacques de Werra (Cheltenham: Edward Elgar Publishing, 2013): 228. 
patentees (typically pharmaceutical companies) - negotiate the terms such as royalties, exclusivities and geographical preferences.

In the past, many companies licensed their products voluntarily ${ }^{34}$, primarily through the Medicines Patent Pool and bilateral agreements. Currently, Gilead has already signed Voluntary Licenses with generic pharmaceutical manufacturers based in Egypt, India and Pakistan to expand supply on a medicine believed to be effective in COVID-19 treatment. ${ }^{35}$

This type of license also reduces treatment costs, therefore benefiting the national economy by boosting savings and stimulating the local generic industry. With the local production, inventors may see their drugs being improved by new formulations, which incentivises future licensing discussions and strengthens a relationship (that is usually strained), building good-will between generic firms and pharmaceutical companies.

Notwithstanding, all this depends on the agreed terms and conditions. Bilateral Voluntary Licenses' agreements have been criticized for lack of transparency, since they are (contrary to Patent Pools' Voluntary Licenses) confidential, which may lead to second parties allowing more restrictive provisions unknowingly. ${ }^{36}$ High royalties rates and geographical exclusions are also negative possibilities. Altogether, such disadvantages can have the adverse desired effect: impede access to medicines.

Voluntary Licenses granted under Patent Pools are, at least, more transparent, which means the use of this mechanism to access treatment to COVID-19, with balanced terms and conditions, would fulfil the preferences of patentees and promote public health. Nonetheless, Patent Pools are not very popular. Both the pharmaceutical industry and the wealthiest countries opted out of Patent Pools. ${ }^{37}$

34 Access to Medicine Foundation, Access to Medicine Index 2016 Overall Ranking, (Haarlem: Access to Medicine Foundation, 2016): 8-11, 63-77, https://accesstomedicinefoundation.org/ publications/2016-access-to-medicine-index; K D Raju, "Compulsory v Voluntary Licensing: A Legitimate way to Enhance Access to Essential Medicines in Developing Countries", Journal of Intellectual Property Rights 22, (January 2017): 27.

35 "Voluntary Licensing Agreements for Remdesivir", Gilead, 2020, https://www.gilead.com/purpose/advancing-global-health/covid-19/voluntary-licensing-agreements-for-remdesivir.

36 Foss-Solbrekk, “Safeguarding public health," 88.

37 Mari Serebrov, "Biopharma opts for collaboration, not patent pools", Blog, BioWorld, August 25, 2020, https://www.bioworld.com/articles/496984-biopharma-opts-for-collaboration-not-patent- 


\subsection{Waiving TRIPS Intellectual Property Rights provisions}

This no-cooperative behaviour from the powered actors led India and South Africa to present before World Trade Organization (WTO), in October 2020, a proposal to waive the TRIPS Intellectual Property Law provisions for COVID-19 related medical technologies during the current pandemic ${ }^{38}$. Signed by most least developed countries, developing countries and intergovernmental and international organization ${ }^{39}$, which believe this waiver will eliminate the problems of TRIPS flexibilities, such as vaccine inequality access and time-intensiveness. These flexibilities are believed not to be sufficient to answer the pandemic. ${ }^{40}$

For example, one main argument is that the waiver offers easy access not only to patents, but to copyrights and industrial designs, which are not included in Compulsory Licensing flexibility. As affirmed by Carlos Correa, the waiver will address all the existent problems of access to medicines altogether, the limitations and pressures Compulsory Licensing system do not resolve and may even deepen. ${ }^{41}$

Nonetheless big pharmaceutical and wealthiest countries are opponents of the proposal. ${ }^{42}$ Arguments presented state that the obstacles are not intellectual property rights, but the lack of the essential means to production facilities, infrastructures and know-how -, meaning that even if the TRIPS

pools, and Ed Silverman, "The WHO launched a voluntary COVID-19 product pool. What happens next?", Blog, STAT, May 29, 2020, https://www.statnews.com/pharmalot/2020/05/29/whocovid19-coronavirus-patents/.

38 World Trade Organization, "Waiver From Certain Provisions Of The Trips Agreement For The Prevention, Containment And Treatment Of Covid-19", IP/C/W/669, October 2, 2020, https://docs.wto.org/dol2fe/Pages/SS/directdoc.aspx?filename=q:/IP/C/W669. pdf\&Open $=$ True

39 Médicines Sans Frontières, India and South Africa proposal for WTO waiver from intellectual property protections for COVID-19 related medical technologies, (Geneva: Médicines Sans Frontières, November 18, 2020): 2.

40 Médicines Sans Frontières, "WTO COVID-19 TRIPS waiver proposal" : 4, https://msfaccess. org/sites/default/files/2020-12/COVID_TechBrief_MSF_AC_IP_TRIPSWaiverMythsRealities_ ENG_Dec2020.pdf.

41 Andrew Green. "At WTO, a battle for access to COVID-19 vaccines," Devex, December 15, 2020, https://www.devex.com/news/at-wto-a-battle-for-access-to-covid-19-vaccines-98787

42 Médicines Sans Frontières, "TRIPS waiver proposal”. 
Waiver is accepted, the complex manufacturing required to develop the vaccine would not yet exist in developing countries, and even in some high income countries, meaning that the issue of under-supply would persist. ${ }^{43}$

Moreover, if this Proposal is approved, incentive to future innovation may disappear and companies will stop sharing valuable patents, technologies and trade secrets. High income countries argue that "equitable access can be achieved through voluntary licensing, technology transfer arrangements, and the donor-funded COVAX Advance Market Commitment ${ }^{44}$ for vaccines" and even the WHO Solidarity Trial of COVID-19 treatments' Chairmen agrees that the patent waiver is a "wrong approach".45

Indeed, at first sight, the optimal solution for our problematic would be for companies to voluntarily given up of their Intellectual Property Rights, as Moderna, who will not enforce its patents and will license its COVID19-related patents with other vaccine manufacturers. ${ }^{46}$ Nevertheless, pharmaceutical industries cannot be obliged to take this conduct.

\section{Conclusion}

Considering the options presented above, although the Proposal of TRIPS Waiver would be a good solution for the present pandemic, it can compro-

43 Katie Gallogly-Swan, "TRIPing Up: Why Global Access to the Covid-19 Vaccine Lies with the WTO", Blog, Global Development Policy Center, December 22, 2020, https://www.bu.edu/ gdp/2020/12/22/tripping-up-why-global-access-to-the-covid-19-vaccine-lies-with-the-wto/

44 According to WHO (“COVAX”, World Health Organization, https://www.who.int/initiatives/ act-accelerator/covax) and GAVI ("COVAX explained”, GAVI, https://www.gavi.org/vaccineswork/ covax-explained?gclid=Cj0KCQjwmIuDBhDXARIsAFITC_6gfMTnncqc1qyeF0c_0tmHiYe1j5B1Elf4IUntXrweGWhXoX9_P8aAg8GEALw_wcB), COVAX is the vaccines pillar of the Access to COVID-19 Tools (ACT) Accelerator, "a ground-breaking global collaboration to accelerate the development, production, and equitable access to COVID-19 tests, treatments, and vaccines", and COVAX aims to "accelerate the development and manufacture of COVID-19 vaccines, and to guarantee fair and equitable access for every country in the world" by "acting as a platform that will support the research, development and manufacturing of a wide range of COVID-19 vaccine candidates, and negotiate their pricing". As stated by Serebrov, "Biopharma": "Instead of pooling patents, COVAX offers a procurement mechanism".

45 Gallogly-Swan, “TRIPing UP”.

46 Robert Langreth and Susan Decker, "Moderna Won't Enforce Covid Vaccine Patents During Pandemic", Blog, Bloomberg, October 8, 2020, https://www.bloomberg.com/news/articles/2020-10-08/ moderna-won-t-enforce-patents-on-covid-vaccines-during-pandemic . 
mise future (and very probable) health crises. The right to health shall outweigh intellectual property rights but not excessively. The Intellectual Property system is required to incentivise new inventions on biomedicine, which might dry up in its absence..$^{47}$ Inventors may reconsider their participation in future disease outbreaks battles if their rights are easily neglected. Moreover, even if it is approved, its effective fulfilment will depend entirely on the will and actions of the WTO Member States. ${ }^{48}$

Nevertheless, the Proposal is still waiting to be revisited by $\mathrm{WTO}^{49}$ and meanwhile, governments must take action.

Inventors and investors on biotechnology industry do not opt for Patent Pools or subscribe this proposal ${ }^{10}$ and ask for collaboration instead. Voluntary licenses are their preference. However, this legal mechanism may lead to difficulties on the access to medicines, if patentees contractual stipulation freedom is wider.

In our opinion, Patent Pools would be the perfect fit, since they are the most effective solution in terms of time, their main disadvantages were already surpassed and they would promote transparent Voluntary Licenses. However, if patentees do not adhere, it is a mechanism just as effective as WTO Members without national legislation on Compulsory Licensing.

Taking these statements into consideration, we conclude that if Compulsory Licensing issues are surpassed - which they can be if countries improve their regimes and opt-back into 31bis TRIPS — this figure may be the best

47 Ann Danaiya Usher, "South Africa and India push for COVID-19 patents ban", The Lancet 396, no. 10265 (December 2020), https://www.thelancet.com/journals/lancet/article/PIIS01406736(20)32581-2/fulltext .

48 As stated by Praharsh Gour, "Wishful Thinking? Analyzing India and South Africa's Joint Statement to Waive Key Provisions of TRIPS - Part II”, Blog, Spicy IP, October 20, 2020, https://spicyip. com/2020/10/wishful-thinking-analyzing-india-and-south-africas-joint-statement-to-waive-keyprovisions-of-trips-part-ii.html .

49 World Trade Organization, "Members to continue discussion on proposal for temporary IP waiver in response to COVID-19", December 10, 2020, https://www.wto.org/english/news_e/ news20_e/trip_10dec20_e.htm.

50 As Pascal Soriot affirms: "IP is a fundamental part of our industry. And if you don't protect IP, then essentially there's no incentive for anybody to innovate." In his words, it was because of strong IP that the biopharma industry was robust and able to respond so quickly to a global pandemic. Serebrov, "Biopharma". 
general solution. If not, at least Compulsory Licenses are an essential plan B that countries should not be afraid to adopt.

Despite being considered a threat and very complex to be perfect, Compulsory Licensing is a way to escape expropriation and also to promote Voluntary Licenses that favour both parties ${ }^{51}$ : if States threaten pharmaceutical companies with Compulsory Licenses, patentees will try to negotiate for Voluntary Licenses with better prices and conditions.

At the end of the day, Compulsory Licensing is still the recommended option. ${ }^{52}$ The problems of time and inequality in access to vaccines due to national Compulsory Licenses' laws is already being surpassed by some: since March, many nations amended national regimes to facilitate its process and remove potential roadblocks. This was the case of Australia, Canada ${ }^{53}$, Germany ${ }^{54}$, Hungary and France. Others have passed resolutions to encourage it, such as Ecuador ${ }^{55}$ and Chile ${ }^{56}$.

If no other alternative is presented, Compulsory Licensing continues to be the option that is safer and that allows access to all countries, independently of their economic power, to medicines, since States can use them whenever they understand necessary to their citizens (as long as the requirements are fulfilled). At the same time, the rights of the patent's holder are properly re-

51 Stating that promoting voluntary licenses is the main objective of compulsory licenses, Fidalgo, "Licenças Compulsórias".

52 Recommending compulsory licenses instead of voluntary licenses: Médecins Sans Frontières, "Voluntary licenses and access to medicines", (October 2020): 3, https://msfaccess.org/voluntarylicenses-access-medicines .

53 "Canada notifies WTO on Bill C-13 to facilitate compulsory licensing in the COVID-19 response”, Blog, Knowledge Ecology International, April 26, 2020, https://www.keionline.org/32837 .

54 WIPO, "Germany: Act on the Protection of the Population in the Event of an Epidemic Situation of National Importance", March 27, 2020, https://www.wipo.int/news/en/wipolex/2020/ article_0008.html.

55 Comisión de Educación, Cultura y Ciencia y Tecnología, "Resolución para requerir al Gobierno Nacional el establecimiento de licencias obligatorias y otras medidas que permitan garantizar el acceso gratuito y a costos asequibles de los productos farmacéuticos y tecnologías médicas en la Declaratoria de Emergencia Sanitaria por la pandemia del Coronavirus (COVID-19) y demás variaciones, así como los protocolos e instrumentos de bioseguridad para el personal de salud, posgradistas y estudiante del Sistema de salud público", March 20, 2020, https://www.keionline.org/wp-content/uploads/ES-Ecuador-CL-resolution.pdf.

56 "Proyecto de Resolución para el otorgamiento de Licencias No Voluntarias Contempladas en el Artículo 51 No2 de la Ley No 19.030 de Propiedad Industrial para Facilitar el Acceso y Disponibilidad a los Medicamentos y Tecnologías para la Prevención, Tratamiento y Cura del Coronavirus COVID-19", https://www.keionline.org/wp-content/uploads/resolucioncoronavirus.pdf. 
spected. Moreover, there is no need to wait for a voluntary decision and the existent rights are balanced.

Overall, we can conclude that this discussion reveals that a reform of International Intellectual Property Law, especially TRIPS, is needed more than ever. ${ }^{57}$ TRIPS flexibility provisions are only a limited solution, with many complications. Health crises will continue to exist and measures must be taken to prepare national and international legislation to effectively address them.

International cooperation, rather than division, is the key to surpass this global emergency in the most effective way without deeply compromising intellectual property rights to a point where there is no more incentive for innovation and inventiveness. Protecting them in this pandemic is necessary to ensure that, in future crises, industry and investors will be, once again, rushing to find solutions. However, these parties shall also make their part and understand the importance of their actions to the universal and presently affected right to health.

57 Mentioning the need for a reform: Sir Colin Birss' MIP International Patent Forum speech, as highlighted by Christian Dekoninck et al., "COVID-19 and public compulsory licensing of drugs in Europe", Blog, Taylor Wessing, April 17, 2020, https://www.taylorwessing.com/fr/ insights-and-events/insights/2020/04/covid-19-and-public-compulsory-licensing-of-drugs-in-europe; Carlos Correa, as presented in Gallogly-Swan, "TRIPing UP,". 